\title{
Antibacterial Peptides from Tryptic Hydrolysate of Ricinus communis Seed Protein Fractionated Using Cation Exchange Chromatography
}

\author{
Tri Joko Raharjo*, Woro Murti Utami, Atdrian Fajr, Winarto Haryadi, Respati Tri Swasono
}

Department of Chemistry, Faculty Mathematics and Natural Sciences, Universitas Gadjah Mada, Bulaksumur, Yogyakarta, Indonesia, 55281

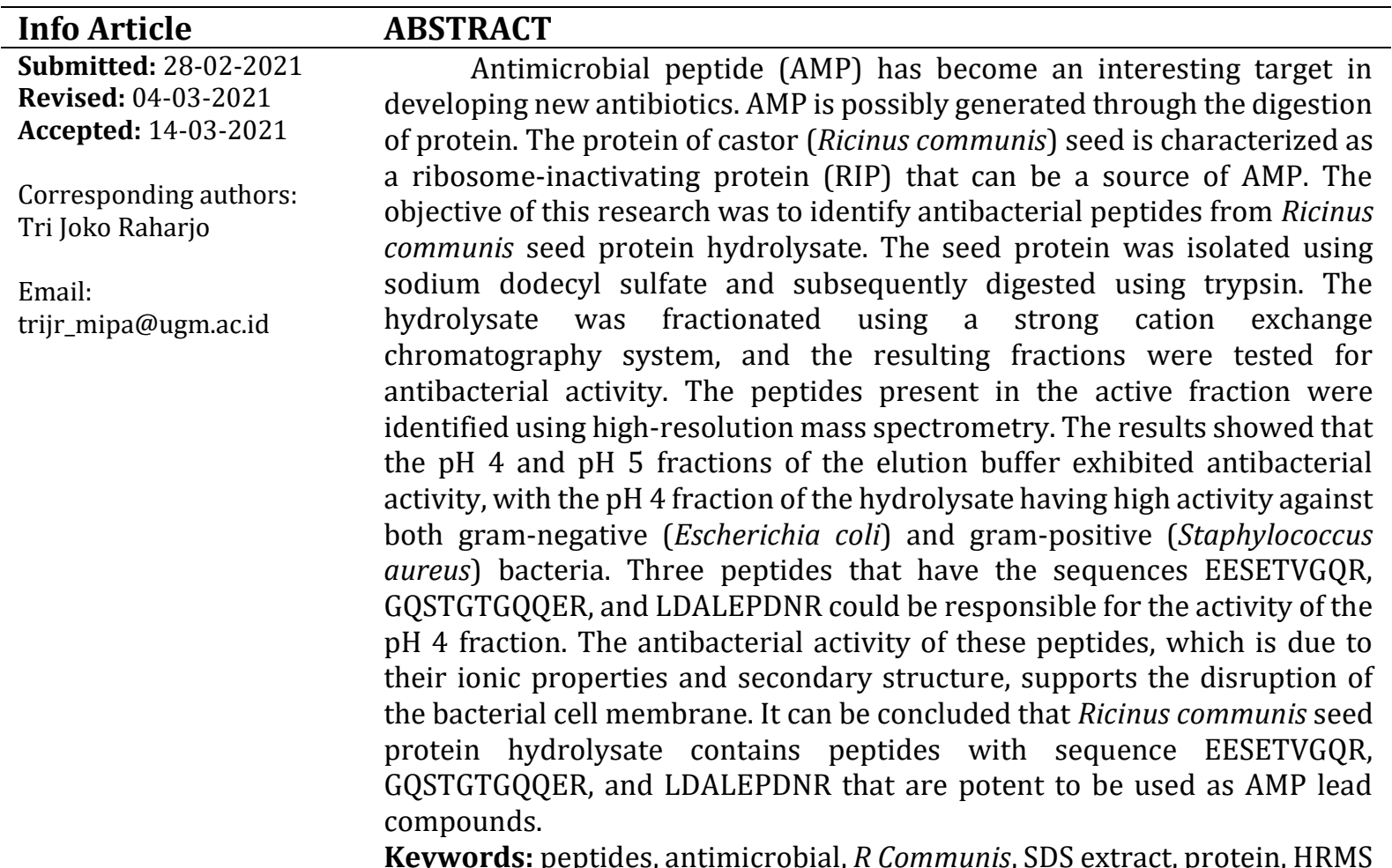

\section{INTRODUCTION}

The treatment of bacterial infections and diseases using antibiotics is currently facing problems because of bacterial resistance to existing antibiotics. In 2015, the United States Centers for Disease Control and Prevention reported that antibiotic-resistant pathogenic bacteria, including Clostridium difficile, caused 15,000 deaths annually in the United States (Dodds, 2017). Ironically, the development of new antibiotics is relatively slower than that of other medicines (Aminov, 2016).

Peptides are interesting targets to study for their potential as antibacterial compounds because their structures vary depending on the amino acid sequence and peptide length. Some natural peptides, such as thionin (plant peptides), bombinin, and cecropin (insect peptides) have been used as the basis for the development of antibiotics. Synthetic peptide antibiotics, such as gramicidin and bacitracin, have been successfully developed from natural peptides. Chemically, most antibacterial peptides contain the tip of weakly loaded amino acids, such as arginine (R) and lysine (K) (Hancock et al., 2006). This phenomenon is related to the biosynthesis of antibacterial peptides, which involves the enzymatic proteolytic hydrolysis of protease against polypeptides.

Hundreds of antibacterial peptide compounds have been reported in the past 50 years. Peptides are classified into non-ribosomal and ribosomal peptides, such as polypeptides. Antibacterial peptides (i.e., non-ribosomesynthesized peptides) are peptides that are biosynthesized in bacteria and fungi, which contain parts derived from two or more amino acids. Penicillin can be considered a peptide derivative because of the amino acid residues of L-cysteine and D-valine in its structure. Some non-ribosomal 
peptide antibiotics sourced from microbes are gramicidin, bacitracin, glycopeptides, and polymyxins (Xue et al., 2018; Zhao et al., 2018). The mechanism of action of this antibiotic group mostly follows the cationic mechanism whereby positively charged peptides (e.g. gramicidin can have +15 charge) damage the cell membrane except for streptogramin which inhibits protein synthesis (Hancock et al., 2006).

Melittin from snake venom is the first antibacterial ribosome-targeting peptide to be reported (Habermann, 1972). Melittin activity follows the cationic mechanism. The discovery of melittin has triggered the exploration of cationic peptides from other sources, such as mammals (defensins), amphibians (bombinin), insects (cecropin), and plants (thionin) (Habermann, 1972; Berrocal-Lobo et al., 2009; Parisi et al., 2019). The absence of homologous patterns of specific amino acid sequences for antibacterial ribosometargeting peptides makes it difficult to develop the peptides synthetically. Mammalian peptides, such as azurocidin, lactoferrin, cathepsin, and cathelicidin, exhibit specificity to mycobacteria; thus, they can be developed into antituberculosis drugs (Padhi et al., 2014). Moreover, mammalian endophytic microbes have been reported to be a source of antibacterial peptides. Short peptides with 16 amino acids (ASVVNLKLTGGVAGLLK) are produced by Bacillus bacteria in the pig's intestinal tract. These peptides have been reported to have a low MIC value against Escherichia coli $(2.5-5 \mu \mathrm{M})$ and Staphylococcus aureus (10-20 $\mu \mathrm{M}$ ) (Xin et al., 2017).

The latest development in the study of antibacterial peptides is peptides resulting from the hydrolysis of proteins with proteolytic enzymes. Enzymatic cutting of polypeptides can be done in vitro to produce peptides with different characteristics (i.e., size and sequence of amino acids). Peptides with R or K tips can be produced with a specific peptidase enzyme, such as trypsin. Similar to isolated natural peptides, peptides hydrolyzed from proteins vary from those derived from higher organisms. Purification of peptides from the hydrolysis of pepsin protein from Brucea javanica fruit produced brucine, an antibacterial peptide with the amino acid sequence HTLCMAGGATY, with activity against Streptococcus pyogenes 16 times higher than penicillin (Sornwatana et al., 2013). Antibacterial peptides hydrolyzed from plant proteins obtained from the hydrolysis of pepsin against RuBisCO, which was isolated from alfalfa, have three short peptides (i.e., three, five, and six amino acids) with antibacterial activity against both gram-positive and gramnegative bacteria (Kobbi et al., 2015). Antibacterial peptides have also been reported to be obtained from the hydrolysis of seed proteins. Song et al. (2020) reported three peptides with highly active antibacterial activity identified from cottonseed protein hydrolysate. Antibacterial peptides have also been reported to be obtained from the hydrolysis of animal proteins. Sila et al. (2014a) reported eight peptides of three and four amino acid residues resulting from the hydrolysis of barbel fish protein. The mechanism of action of these peptides involves damaging cell membranes. The hydrophobic amino acid sequences in these peptides form a structure of random peptide coil, which is related to antibacterial activity according to Sila et al. (2014b). The hydrolysis of cow's milk casein protein with metallocene protease has been reported to produce antibacterial peptides identified using MALDI-TOF as having the amino acid sequence of SSSEESII. This peptide also has a random coil structure and inhibitory activity against gram-positive and gram-negative bacteria (Bougherra et al., 2017). The hydrolysis of proteins that produce antibacterial peptides has also been reported for the macroalgae Saccharina longicruris hydrolyzed with trypsin. The hydrolysate can inhibit the growth of S. aureus at a concentration of $0.31 \mathrm{mg} / \mathrm{mL}$. Nine peptides with sizes ranging from 8 to 16 amino acids, with predominantly arginine at the end, were identified. The mechanism of action of these peptides follows the cationic mechanism (Beaulieu et al., 2015).

Ribosome-inactivating protein (RIP) from Phytolacca dioica has been reported to be hydrolyzed at the amino acid positions $40-65$ to produce a peptide known as PDL440-65, which exhibits antibacterial activity. This peptide has a broad spectrum of activity against E. coli, S. aureus, Pseudomonas aeruginosa, and Agrobacterium tumefaciens. In contrast to other antibacterial peptides, PDL440-65 has a $\beta$-sheet structure (Pizzo et al., 2015). The discovery of PDL440-65 has enabled large-scale research on other RIPs, such as ricin, to potentially produce antibacterial peptides that can be developed into antibiotics. The amino acid sequence pattern of antibacterial peptides reported so far can be said to be erratic, but most antibacterial peptides follow ionic mechanisms that involve damaging bacterial cell membranes. 
Jatropha (Ricinus communis) seeds contain $1 \%$ to $5 \%$ of a special protein called ricin, which is toxic because it is a RIP (Wilson et al., 2018). RIP inhibits protein biosynthesis, which is one of the mechanisms of action of antibiotics. Peptides with RIP activity that also exhibit antibacterial activity have been reported (Balaban et al., 2000). Meanwhile, peptides with antibacterial activity have been successfully obtained from the RIP of the plant P. dioica (Pizzo et al., 2015). Based on previous findings, ricin and castor seed proteins, which have RIP activity, are hydrolyzed to produce peptides that have antibacterial activity. This study aimed to reveal the antibacterial activity of peptides obtained from the tryptic hydrolysis of castor seed protein.

\section{MATERIALS AND METHOD}

The main materials used in peptide preparation were castor beans ( $R$. communis) (EcoWell, Indonesia), sodium dodecyl sulfate (SDS; Merck, Germany), trypsin (Bioworld, OH, USA), and cation exchange SPE column (Discovery DSC-SCX; Supelco, PA, USA). The antibacterial activity test used E. coli (ATCC), S. aureus (ATCC), and a solid medium containing tryptone, yeast extract, yeast agar (Oxoid, Ireland) as the inoculant. Acetonitrile (hyper grade for LC-MS LiChrosolv, Merck, Germany), water (MS grade, Merck, Germany), and trifluoroacetic acid (TFA; Merck, Germany) were used during peptide identification.

\section{Protein extraction}

Dry seeds were ground into powder and defatted before extraction. Castor seed powder was extracted using $0.01 \%$ SDS at room temperature for $12 \mathrm{~h}$ and dialyzed against a $50 \mathrm{mM}$ Tris- $\mathrm{HCl}$ buffer (pH 7.5) overnight at $4^{\circ} \mathrm{C}$. After sonication for $15 \mathrm{~min}$, the mixture was centrifuged. The protein extract was obtained from the supernatant. Then, the protein content was measured using a UV-Vis spectrophotometer at a wavelength of $280 \mathrm{~nm}$ (Utami, 2019).

\section{Protein hydrolysis}

The extracted protein was hydrolyzed with trypsin using an enzyme-to-protein ratio of $1: 10$ $(\mathrm{w} / \mathrm{w})$. The mixture was incubated for $24 \mathrm{~h}$ at $37^{\circ} \mathrm{C}$ and further incubated for $15 \mathrm{~min}$ at $80^{\circ} \mathrm{C}$. Protein hydrolysate was collected from the supernatant after $10,000 \times \mathrm{g}$ centrifugation for $10 \mathrm{~min}$ at room temperature. The degree of hydrolysis that occurred in $900 \mu \mathrm{L}$ of protein hydrolysate mixed with $100 \mu \mathrm{L}$ of $10 \%$ trichloroacetic acid solution was determined. The solution was incubated for $10 \mathrm{~min}$ at room temperature, followed by $8,000 \times \mathrm{g}$ centrifugation for $10 \mathrm{~min}$. The supernatant was separated, and its absorbance was measured using a UV-Vis spectrophotometer at a wavelength of 280 $\mathrm{nm}$. The level of hydrolysis was expressed as the ratio of the percentage of absorbance after and before enzymatic hydrolysis (Sornwatana et al., 2013).

\section{Peptide fractionation}

The column was pretreated with methanol and distilled water at a flow rate of $1-3 \mathrm{~mL} / \mathrm{min}$. After washing with distilled water, the column was conditioned using a pH 3 buffer. Protein hydrolysate $\mathrm{pH} 3$ was applied to the column slowly. Then, the sample was propelled at a flow rate of 1$3 \mathrm{~mL} / \mathrm{min}$ and stopped when the sample level was directly above the adsorbent. Elution was performed with $\mathrm{pH} 4,5,6,7$, and 8 buffers in sequence at a flow rate of $1-3 \mathrm{~mL} / \mathrm{min}$ to obtain eluate as much as twice the column volume. Each elution of the same $\mathrm{pH}$ was collected into one fraction and neutralized to $\mathrm{pH}$ 7. The eluate obtained was freeze-dried and redissolved in distilled water. Each fraction was used to determine the amount of peptide that was eluted by measuring its absorbance at $280 \mathrm{~nm}$ (Fajr, 2019).

\section{Antibacterial activity test of the protein hydrolysate fraction}

The antibacterial activity test was performed using the disk diffusion method. The inoculants (i.e., E. coli and S. aureus) were made by growing test bacteria from the stock solution on LB media (made from a mixture of tryptone, yeast, and $\mathrm{NaCl}$ at a ratio of 2:1:1 in distilled water). Bacteria were grown until their turbidity (OD) reached $0.5-0.7$, which was determined by measuring their absorbance at a wavelength of $600 \mathrm{~nm}$. The inoculants were mixed with the melted agar medium at a ratio of 1:100 (1\%), homogenized, and poured into a sterile Petri dish. Disk paper was diluted with a test solution (peptide fraction, $15 \mu \mathrm{g}$ ) and affixed to the frozen media. The positive control used was amoxicillin $(10 \mu \mathrm{g})$, and the negative control used was sterile distilled water. The disk paper was incubated overnight at $37^{\circ} \mathrm{C}$. Then, the diameter of the clear zone or zone of resistance that formed around the disk paper was measured. 


\section{Identification of antibacterial peptides in hydrolysate fractions}

Peptides in the fraction were separated using a liquid chromatography system equipped with the Acclaim ${ }^{\circledR}$ PepMap RSLC column (C18, $1 \mathrm{~mm} \times 150 \mathrm{~cm}$, with a particle size of $3 \mu \mathrm{m})$. The peptides in the column were eluted using gradient mobile phases composed of $0.05 \%$ TFA in water (mobile phase A) and water/acetonitrile at a ratio of $20: 80$ and $0.1 \%$ TFA (mobile phase B). Mobile phase containing $96 \% \mathrm{~A}$ and $4 \% \mathrm{~B}$ flowed at $0.3 \mu \mathrm{L} / \mathrm{min}$ from $0 \mathrm{~min}$ to $2.99 \mathrm{~min}$, changed to $90 \% \mathrm{~A}$ and $10 \% \mathrm{~B}$ at the $3^{\text {rd }}$ min, changed linearly to $80 \% \mathrm{~A}$ and $20 \% \mathrm{~B}$ at the $30^{\text {th }} \mathrm{min}$, and changed to $5 \% \mathrm{~A}$ and $95 \% \mathrm{~B}$ at the $70^{\text {th }}$ min and maintained until the $90^{\text {th }}$ min. MS and tandem mass spectrometry (MS/MS) analyses were conducted using the electrospray ionization method. The positive ion mode, which is operated with high resolution and accurate mass mode, was used for MS detection. MS/MS peptide analysis used the $\mathrm{m} / \mathrm{z}$ range of 350-1,800 with full-MS/dd-MS2 mode. The resolving power was set at 140,000 full width at half maximum (FWHM) for the full-MS scan. Meanwhile, the resolution was set at 17,500 FWHM for the dd-MS2 scan.

For peptide identification, the MS raw data were processed using the Proteome Discoverer Software ver. 2.2. Peptide identification was done by processing data using the Fusion Basic Sequest HT workflow and a basic consensus workflow. The algorithm used in peptide analysis is Sequest HT. The database used is a genomic database of castor bean plantations ( $R$. communis), which was downloaded from UniProt.org (The UniProt Consortium, 2019). Peptide identification was completed by comparing the research data with the database used.

\section{RESULTS AND DISCUSSION \\ Production of the jatropha seed protein hydrolysate}

SDS, a biomolecule-solubilizing agent is widely used to treat protein before polyacrylamide gel electrophoresis. This is known as the sodium dodecyl sulfate-polyacrylamide gel electrophoresis (SDS-PAGE) technique. The use of SDS to extract protein is preferable to strong acid and base because it disrupts the secondary, tertiary, and quaternary structures of protein without any hydrolytic side effects (Zhou et al., 2012). The extraction of protein from castor beans using $0.01 \%$ SDS yielded up to $20.94 \%$ of fat-free seed powder. This yield was quite high considering that the seed is not only composed of protein, and the concentration of SDS used was low. These results are consistent with those obtained by Lacerda et al. (2014) who were able to extract protein from Jatropha seed, with up to $11.4 \%$ to $27.3 \%$ yield. The increase in SDS concentration increased the yield of the extraction process. However, because the protein would be subjected to downstream processes, including enzymatic digestion and MS analysis, the use of a high concentration of SDS was avoided. At a concentration of $0.1 \%$, SDS could inhibit protease enzymes such as trypsin, because it disrupts the secondary and tertiary structures of trypsin. A higher concentration of SDS could lead to ion suppression that interferes with ion exchange fractionation and MS analysis of the peptides (Scheerlinck et al., 2015).

Dialysis was performed to remove small molecules including SDS, obtained from the extract before tryptic digestion. A clean extract could ensure the success of the digestion process, as indicated by the degree of hydrolysis. Trypsin hydrolysis was able to digest up to $82.15 \%$ of Jatropha seed protein, as indicated by the hydrolysis data. This high result was supported by the quality of trypsin that exhibited an activity of up to $2,500 \mathrm{U} / \mathrm{mg}$. A high degree of hydrolysis is unnecessary in peptide identification. Sornwatana et al. (2013) succeeded in identifying active peptides from protein hydrolysate, with a $3.7 \%$ degree of hydrolysis. However, a large amount of unhydrolyzed protein present in hydrolysate could hinder peptide identification. Therefore, extra preparation is essential before MS analysis.

\section{Antibacterial activity of the protein hydrolysate fraction}

The peptides obtained from trypsin hydrolysis were fractionated using a cation exchange SPE column. SPE is mainly used to concentrate trace organic compounds to enable detection using certain analytical tools. However, ion exchange SPE, where $\mathrm{pH}$ or ionic strength gradient could be employed during elution, makes fractionation possible. Several reports proposed the use of SPE for fractionation (Fauland et al., 2013; Cutignano et al., 2015) and obtained satisfying results. SPE fractionation of the Jatropha seed protein hydrolysate was performed using a strong cation exchange SPE column and fractions were collected on the basis of the $\mathrm{pH}$ of the elution buffer varying from $\mathrm{pH} 4$ to $\mathrm{pH} 8$. 
The highest yield of $9.14 \%$ of the total peptides present in the hydrolysate was obtained from the $\mathrm{pH} 4$ fraction, whereas the lowest yield was obtained from the $\mathrm{pH} 8$ fraction. Cation exchange fractionation was chosen because it is compatible with the separation process. All peptides could be separated because it is easy to achieve a low $\mathrm{pH}$ that renders peptides as cations. Cation exchange fractionation also provided better resolution for peptides than other fractionation techniques, such as IEF and SDS-PAGE (Mostovenko et al., 2013).

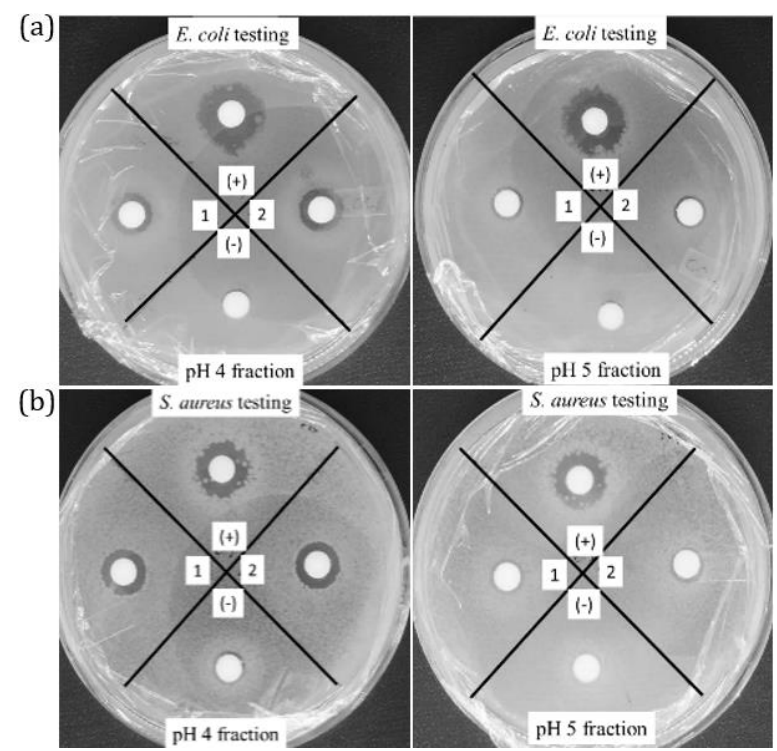

Figure 1. Growth inhibition zones of the $\mathrm{pH} 4$ and $\mathrm{pH} 5$ fractions of $R$. communis seed protein hydrolysate for E.coli (a) and $S$. aureus (b). Amoxicillin and distilled water are used as positive control (+) and negative control ( - ), respectively, and each fraction was replicated (1 and 2 )

Table I. Inhibition zones of the peptide fractions of $R$. communis seed protein hydrolysate for E.coli and S. aureus

\begin{tabular}{ccc}
\hline \multirow{2}{*}{ Sample } & $\begin{array}{c}\text { Diameter of the inhibition } \\
\text { zone (mm) }\end{array}$ \\
\cline { 2 - 3 } & E. coli & S. aureus \\
\hline pH 4 fraction & 4.0 & 4.5 \\
pH 5 fraction & 2.0 & 2.0 \\
pH 6 fraction & 0 & 0 \\
pH 7 fraction & 0 & 0 \\
pH 8 fraction & 0 & 0 \\
Positive control & 9.6 & 6.4 \\
Negative control & 0 & 0 \\
\hline
\end{tabular}

The data show that the $\mathrm{pH} 4$ and $\mathrm{pH} 5$ fractions had antibacterial activity against both $E$. coli and $S$. aureus as representatives of gramnegative and gram-positive bacteria, respectively (Figure 1 and Table I). The disk diffusion method was used because it is a simple and low-cost technique, particularly for compounds with low concentrations, such as natural products or peptides present in the fraction (Das et al., 2010; Caron et al., 2012; Balouiri et al., 2016). Furthermore, the method has been established as a standard method for determining antimicrobial activity (CLSI, 2012). Peptides of the pH 4 fraction exhibited higher antibacterial activity than the $\mathrm{pH} 5$ peptide fraction, as indicated by the diameter of the inhibition zone. The $\mathrm{pH} 4$ fraction has a 4.0 and $4.5 \mathrm{~mm}$ inhibition zone for $E$. coli and $S$. aureus, respectively, whereas the $\mathrm{pH} 5$ fraction has a $2.0 \mathrm{~mm}$ inhibition zone each for both bacteria. However, the activities in the negative control were lower than that in the positive control, even though the amount of peptides $(15 \mu \mathrm{g})$ in the disk was more than the amount of amoxicillin $(10 \mu \mathrm{g})$. The peptide fraction might consist of more than one compound or peptide and not all of the components were active and thus, the actual amount of the active peptides could be lower than that of amoxicillin.

\section{Identification of the antibacterial peptides}

Given that only $\mathrm{pH} 4$ fraction of Jatropha seed protein hydrolysate exhibited interesting antibacterial activity, peptide identification of the fractions was further conducted. Liquid chromatography coupled with tandem mass spectrometry (LC-MS/MS) equipped with an HRMS using de novo peptide sequencing is one of the gold standard methods used for proteomic studies (Syka et al., 2004; Coon et al., 2005; Hunt et al., 2015; Tran et al., 2017). Protein identification could be performed using the peptide sequence tag obtained by MS/MS analysis and the protein and genome database search engine (Nesvizhskii et al., 2007; Cottrell et al., 2011). Meanwhile, the available genome and protein databases of certain species could be used to characterize certain peptides, even though the fragmentation data obtained using MS/MS peptide analysis are incomplete. The genome sequence of $R$. communis is available in GenBank, making peptide identification of $\mathrm{pH} 4$ fraction using the UniProt database possible.

The results of LC-MS/MS analysis of $\mathrm{pH} 4$ fraction using the Orbitrap HRMS are plotted in the total ion chromatogram (TIC) (Figure 2). 


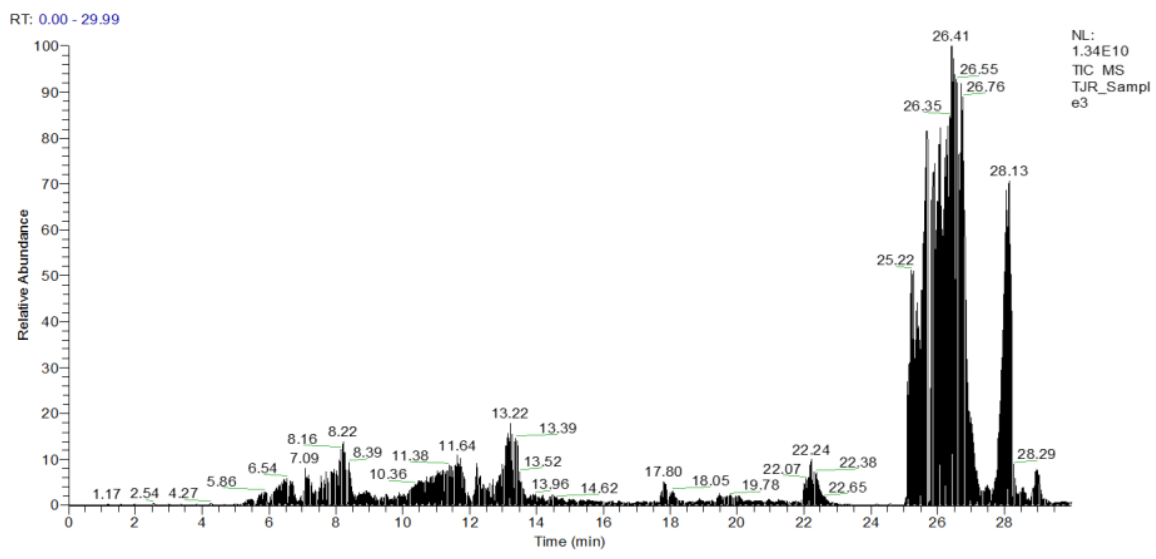

Figure 2. Total ion chromatogram of the $\mathrm{pH} 4$ fraction of $R$. communis seed protein hydrolysate analysis obtained using high-performance liquid chromatography coupled with high-resolution mass spectrometry.
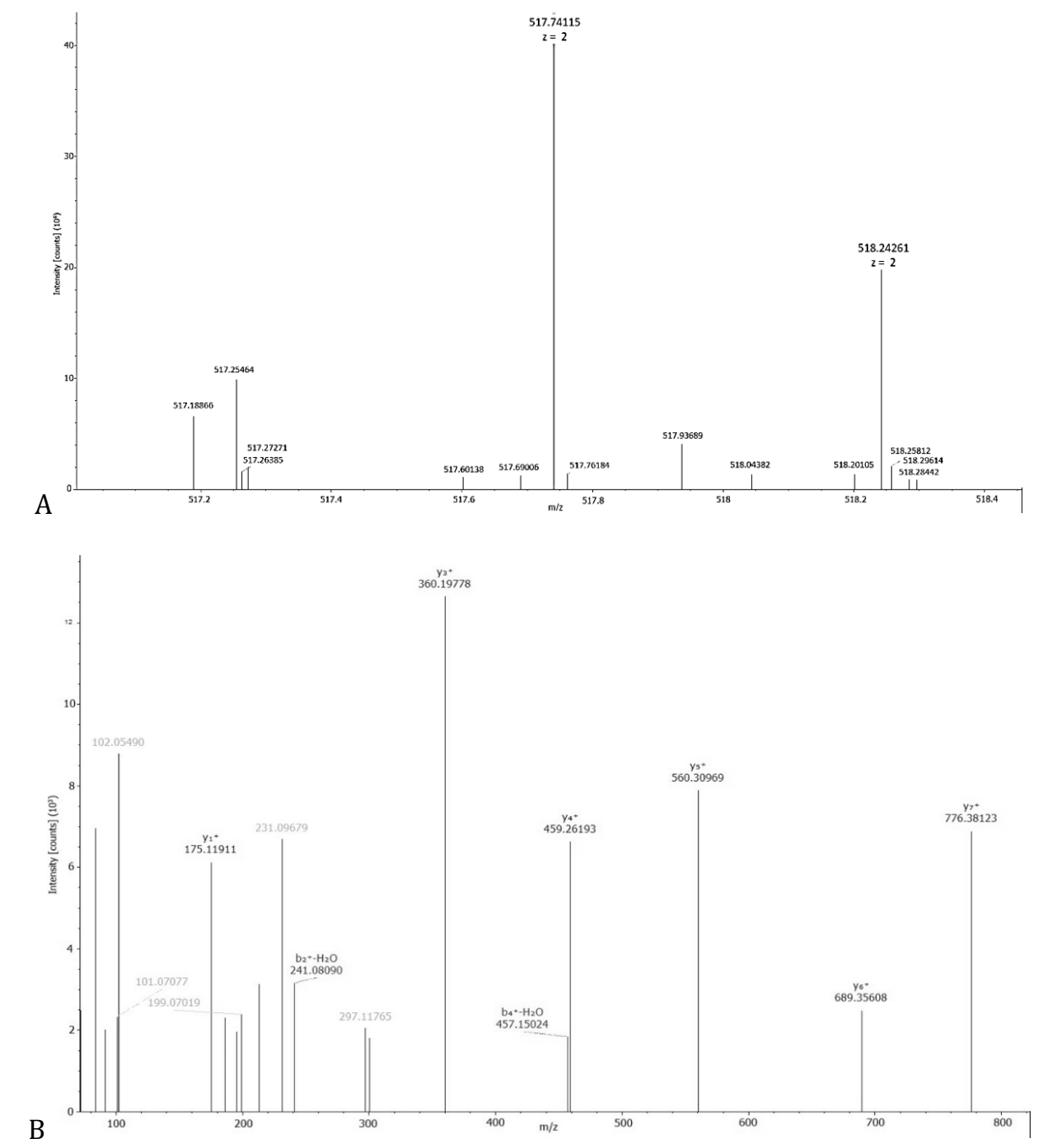

Figure 3. MS spectra of peptide number 1 of the $\mathrm{pH} 4$ fraction of $R$. communis seed protein hydrolysate. MS 1 identifies the isotopic pattern of the peptide ion (a), whereas MS $^{2}$ identifies the $\mathrm{b}^{+}$and $\mathrm{y}^{+}$ions from the peptide fragmentation data (b). 
The TIC shows the raw data of all ions detected using both $\mathrm{MS}^{1}$ and $\mathrm{MS}^{2}$. MS ${ }^{2}$ was performed using data-dependent MS ${ }^{1}$ (dd-MS), with 10 ions of MS ${ }^{1}$ with the highest intensity subjected to collision ionization of $\mathrm{MS}^{2}$. Three MS' data from TIC of $\mathrm{pH} 4$ fraction were confirmed as peptides of Jatropha protein.

The first peptide has $m / z=517.74115(z=2)$ that indicate several isotopic ions with low intensity (Figure 3a). The molecular mass $\left(\mathrm{MH}^{+}\right)$of the peptide is $1,034.47502$, and on the basis of this mass, the peptide is predicted to be composed of 9 to 10 amino acids. The $\mathrm{MS}^{2}$ data of the peptide confirm the presence of several $\mathrm{y}^{+}$ions and two $\mathrm{b}^{+}$ ions and $\mathrm{y}_{1}^{+}$ion=175.1191 representing the $\mathrm{R}$ amino acid of trypsin, confirming the presence of $R$ or $\mathrm{K}$ at the carboxyl (C) terminal of the peptide (Figure 3b). The difference between the $\mathrm{y}_{3}{ }^{+}$ion (360.19778) and the $\mathrm{y}_{1}{ }^{+}$ion (175.11910) is 185.07867, which matches the mass of $Q G$ supported by the presence of the immonium ion (101.07080) of Q. The difference between the $\mathrm{y}_{4}{ }^{+}$ ion (459.26103) and the $\mathrm{y}^{+}$ion is 99.06415, representing the $\mathrm{V}$ amino acid, followed by $\mathrm{T}$ (101.04866), E (129.04639), and S (87.02515), as derived from the difference between the $\mathrm{y}_{5}{ }^{+}$ion (560.30969) and the $\mathrm{y}^{+}$ion, between the $\mathrm{y}^{+}$ion (689.35608) and the $\mathrm{y}_{5^{+}}$ion, and between the $\mathrm{y}^{+}$ ion (776.38123) and the $\mathrm{y}_{6}{ }^{+}$ion, respectively. The interpretation of the $y^{+}$ion confirmed the presence of the sequence SETVGQR of part of the first peptide, according to Proteome Discoverer analysis. The interpretation of the $\mathrm{b}^{+}$ion confirmed the presence of the sequence SE (216.018191), as derived from the difference between the $\mathrm{b}_{4}{ }^{+}$ion (457.15654) and the $\mathrm{b}_{2}{ }^{+}$ion (241.08191). The presence of the strong immonium ion of $E$ (102.05490) indicated the presence of $E$ at the amine end of the peptide [32,33]. The analysis of the MS/MS raw data using the database search engine Proteome Discoverer confirmed the sequence EESETVGQE of the peptide with the molecular mass $\left(\mathrm{MH}^{+}\right)=1,034.47502$. The peptide is part of $2 \mathrm{~S}$ albumin of $R$. communis located at amino acid numbers 129-137.

The $\mathrm{MS}^{1}$ result of the second peptide with $m / z=574.76862(z=2)$ or molecular ion $\left(\mathrm{MH}^{+}\right)=$ 1,148.52995 (Figure 4a). MS ${ }^{2}$ nine $\mathrm{y}^{+}$ions and four $\mathrm{b}^{+}$ions were detected (Figure $4 \mathrm{~b}$ ). The $\mathrm{y}_{1}{ }^{+}$ion $=$ 175.11896 confirms the presence of the $\mathrm{R}$ amino acid at the $\mathrm{C}$ terminal of the peptide. The mass difference between the $\mathrm{y}_{2}{ }^{+}$ion (304.16147) and the $\mathrm{y}_{1}{ }^{+}$ion confirms the presence of $\mathrm{E}(129.04251)$, leading to the sequence $\mathrm{ER}$ at the $\mathrm{C}$ terminal.
Consecutively, the mass difference between the $y_{3}{ }^{+}$ ion (432.21982) and the $\mathrm{y}_{2}{ }^{+}$ion is $128.05858(\mathrm{Q})$, that between the $\mathrm{y}_{4}{ }^{+}$ion $(560.28015)$ and the $\mathrm{y}^{+}$ ion is $128.05858(\mathrm{Q})$, that between the $\mathrm{y}_{5^{+}}$ion (617.30017) and the $y_{4}{ }^{+}$ion is $57.02147(G)$, that between the $\mathrm{y}_{6}{ }^{+}$ion $(718.34924)$ and the $\mathrm{y}_{5}{ }^{+}$ion is $101.04768(\mathrm{~T})$, that between the $\mathrm{y}^{+}$ion (775.36969) and the $\mathrm{y}_{6}{ }^{+}$ion is $57.02147(\mathrm{G})$, that between the $\mathrm{y}_{8}{ }^{+}$ion $(876.41632)$ and the $\mathrm{y}_{7}^{+}$ion is $101.04768(\mathrm{~T})$, and that between the $\mathrm{yg}^{+}$ion (963.44830) and the $\mathrm{y}^{+}$ion is $87.03203(\mathrm{~S})$, which confirm the amino acid sequence STGTGQQER. Meanwhile, additional information was obtained from the interpretation of the $b^{+}$ion mass. The lowest mass of the $b_{2}{ }^{+}$ion, i.e., 186.08737 , indicates that the amine end of the peptide could be QG or GQ. The mass difference between the $\mathrm{b}_{3}{ }^{+}$ion (273.11890) and the $\mathrm{b}_{2}{ }^{+}$ion is smaller than that between $\mathrm{b}_{4}{ }^{+}-\mathrm{H}_{2} \mathrm{O}$ (356.15588) and $\mathrm{b}_{2}{ }^{+}$and that between $\mathrm{b}_{6}{ }^{+}-\mathrm{H}_{2} \mathrm{O}$ (514.22394) and $\mathrm{b}_{4}{ }^{+}-\mathrm{H}_{2} \mathrm{O}$, confirming the sequence identified using the interpretation of the $\mathrm{y}^{+}$ion mass. De novo sequencing of the MS/MS raw data using the Proteome Discoverer database confirmed the presence of the sequence GQSTGTGQQER of the peptide with the molecular mass $\left(\mathrm{MH}^{+}\right)=$ $1,148.52995$. The peptide is part of legumin $\mathrm{B}$ of $R$. communis located at amino acid numbers 125-135.

The MS ${ }^{1}$ result of the third peptide with $m / z$ $=521.76379$ (Figure $5 \mathrm{a}$ ). MS $^{2}$ detected eight $\mathrm{y}^{+}$ions and two $\mathrm{b}^{+}$ions (Figure 5b). The $\mathrm{y}_{1}^{+}$ion $=$ 175.11896 confirms the presence of the $\mathrm{R}$ amino acid at the $\mathrm{C}$ terminal of the peptide. The mass difference between the $\mathrm{yz}^{+}$ion (289.16189) and the $\mathrm{y}_{1}{ }^{+}$ion confirms the presence of $\mathrm{N}$ (114.04293), leading to the sequence $\mathrm{NR}$ at the $\mathrm{C}$ terminal. Consecutively, the mass difference between the $\mathrm{y}_{3}{ }^{+}$ ion (404.18884) and $\mathrm{y}_{2}{ }^{+}$ion is 115.02695 (D), that between the $\mathrm{y}_{4}{ }^{+}$ion (501.24161) and the $\mathrm{y}_{3}{ }^{+}$ion is $97.05277(\mathrm{P})$, that between the $\mathrm{y}_{5}{ }^{+}$ion $(630.28421)$ and the $\mathrm{y}_{4}{ }^{+}$ion is 129.04260 (E), that between the $\mathrm{y}^{+}$ion (743.36828) and the $\mathrm{y}^{+}$ion is 113.08407 $(\mathrm{L})$, that between the $\mathrm{y}_{7^{+}}$ion (814.4054) and the $\mathrm{y}_{6}{ }^{+}$ ion is $71.03712(\mathrm{~A})$, and that between the $\mathrm{y}_{8}{ }^{+}$ion (929.43235) and the $\mathrm{y}^{+}$ion is 115.02695 (D), which confirm the amino acid sequence DALEPDNR. Meanwhile, additional information was obtained from the interpretation of the $\mathrm{b}^{+}$ion mass. The mass of the $\mathrm{b}_{2}{ }^{+}$ion, i.e., 229.11830, indicates the presence of $D(115.02695)$. Therefore, the mass difference between the $\mathrm{b}_{2}{ }^{+}$ion and the $\mathrm{b}_{1}{ }^{+}$ion (D) is equal to 114.09135. The presence of two amino acids, i.e., I and L, indicate two possible sequences at the $\mathrm{N}$ terminal. 


\section{Tri Joko Raharjo}

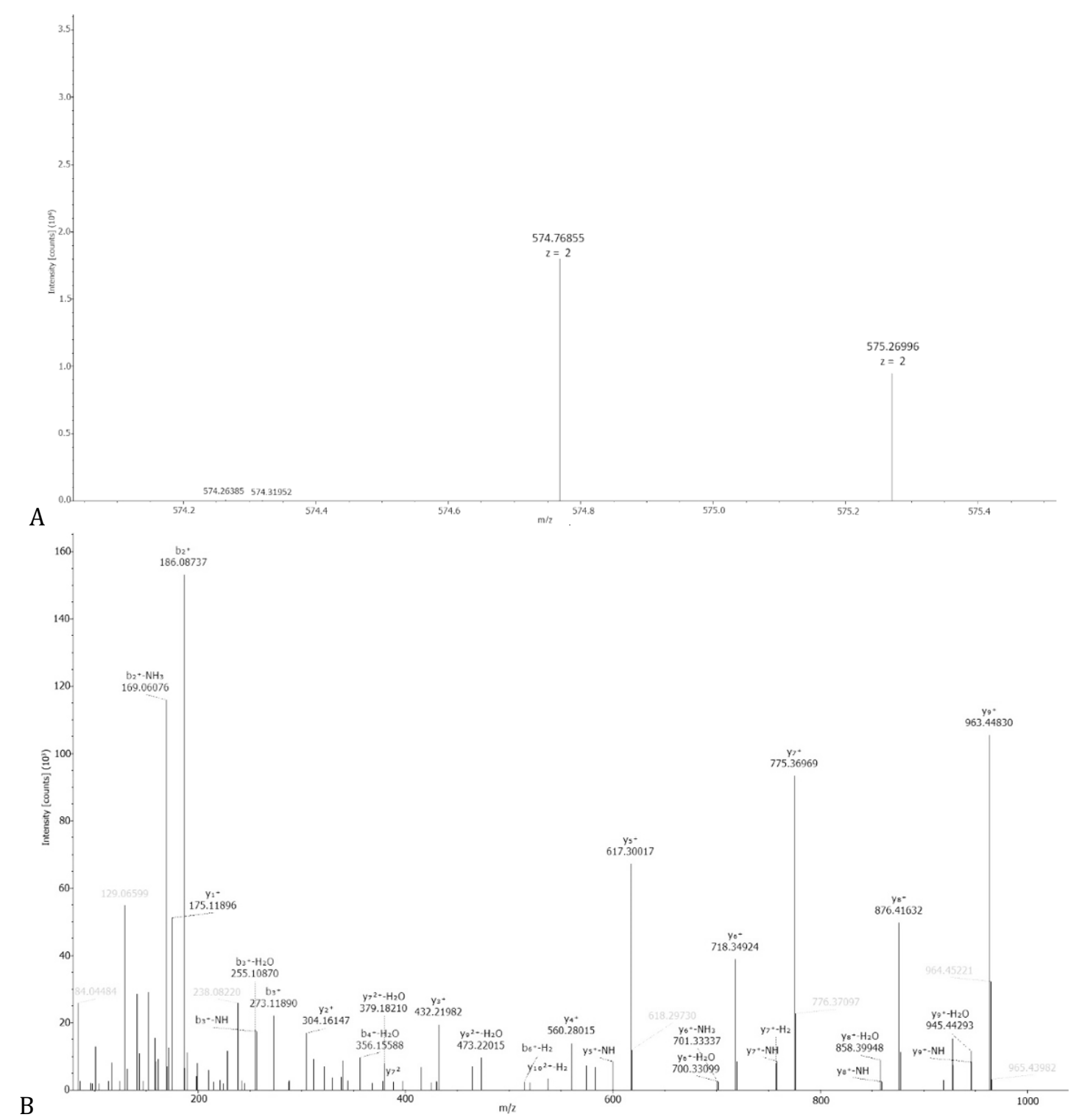

Figure 4. MS spectra of peptide number 2 of the $\mathrm{pH} 4$ fraction of $R$. communis seed protein hydrolysate. MS ${ }^{1}$ identifies the isotopic pattern of the peptide ion (a), whereas MS' identifies the $\mathrm{b}^{+}$and $\mathrm{y}^{+}$ions from the peptide fragmentation data (b).

The analysis of the MS/MS raw data using the Proteome Discoverer database confirmed the presence of the sequence LDALEPDNR of the peptide with the molecular mass $\left(\mathrm{MH}^{+}\right)=1,042.52031$. The third peptide is part of legumin A of $R$. communis located at amino acid numbers 33-41.

The main mechanism of antibacterial compounds is cell lysis due to the inhibition of cell wall biosynthesis through the penicillin mechanism or the disruption of the bacterial cell membrane.
Ionic compounds usually follow the cell membrane disruption mechanism. Several peptide antibiotics, such as gramicidin, bacitracin, and polymyxin, have been successfully developed through this mechanism (Xue et al., 2018; Zhao et al., 2018). Identified peptides from the $\mathrm{pH} 4$ fraction of the Jatropha seed protein hydrolysate (Table II). The amino acid composition shows that all three peptides have ionic properties as only a few amino acids have a nonpolar side chain. 


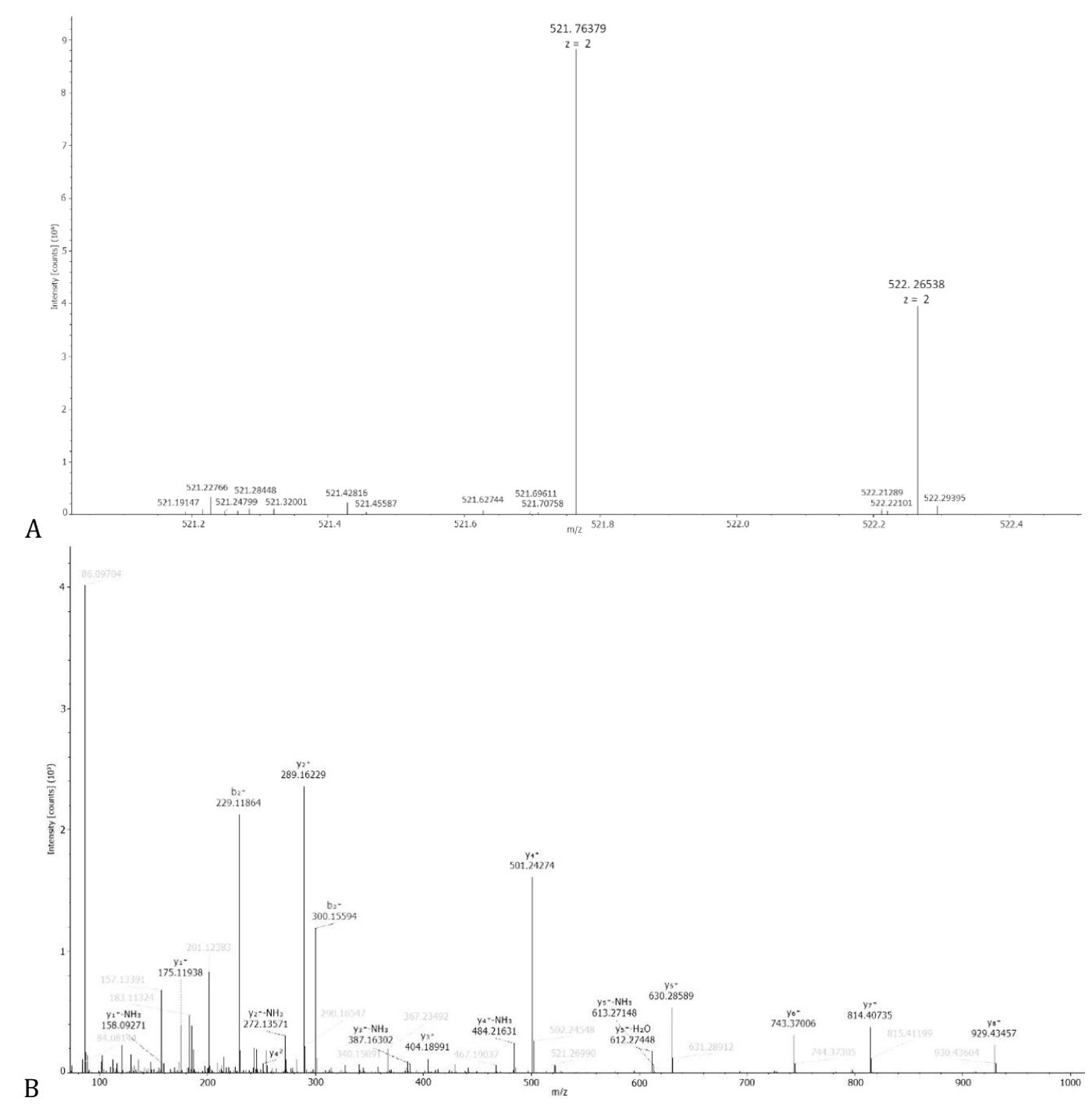

Figure 5. MS spectra of peptide number 3 of the $\mathrm{pH} 4$ fraction of $R$. communis seed protein hydrolysate. MS 1 identifies the isotopic pattern of the peptide ion (a), whereas $\mathrm{MS}^{2}$ identifies the $\mathrm{b}^{+}$and $\mathrm{y}^{+}$ions from the peptide fragmentation data (b).

Table II. Characteristics of the peptides of the $\mathrm{pH} 4$ fraction of the jatropha seed protein hydrolysate

\begin{tabular}{clcccc}
\hline No. & Peptide sequences & Predicted pI & $\mathbf{M H}^{+}$ & Protein of $\boldsymbol{R}$. communis & $\begin{array}{c}\text { Amino acid position } \\
\text { in the protein }\end{array}$ \\
\hline 1 & EESETVGQR & 4.25 & $1,034.47502$ & $2 \mathrm{~S}$ albumin & $129-137$ \\
2 & GQSTGTGQQER & 6.00 & $1,148.52995$ & Legumin B & $125-135$ \\
3 & LDALEPDNR & 4.03 & $1,042.52031$ & Legumin A & $33-41$ \\
\hline
\end{tabular}

According to the predicted pI, the first and third peptides will present strongly as ions at physiological $\mathrm{pH}$, whereas the second peptide will be slightly ionized. The ionic structure of peptides is considered to be responsible for the disruption of the bacterial cell membrane because it could interact with the charged head of the phospholipid bilayer of the cell membrane. The interaction could disrupt the intermolecular hydrogen bonding between phospholipids, leading to the collapse of the cell membrane. 
The secondary structure of the peptide also determines antibacterial activity, where the random coil structure could lead to the disruption of the membrane structure when the peptide interacts with the membrane (Sila et al., 2014a). However, the sequence of the characterized peptides is too short to be modeled to identify their secondary structure. Despite that, on the basis of the secondary structure of the entire protein, the secondary structure of the peptide can be considered as a part of the protein. Modeling of $2 \mathrm{~S}$ albumin, the first peptide identified using JPred 4 (a protein secondary structure prediction server), revealed the sequences of EESETVGQR and EESERVAQR located at the $\beta$-turn between $\alpha$-helix 1 and $\alpha$-helix 2 . Modeling of legumin $B$, the protein where the second peptide originated, also showed that the sequence GQSTGTGQQER is part of the turn between sixth and seventh $\beta$-sheets of the protein. Structural modeling of legumin A, the protein of $R$. communis where the third peptide originated, showed that the sequence LDALEPDNR manifests as a random coil in front of the first $\beta$-sheet structure. All data from the three peptides, which manifests in the ionic form with non-helix and sheet secondary structures according to modeling, support the antimicrobial activity of the peptide fraction containing these peptides.

\section{CONCLUSION}

The protein of jatropha (R. communis) seed can be a source of antibacterial peptides. Tryptic digestion of protein, followed by cation exchange fractionation, showed that the $\mathrm{pH} 4$ fraction of the hydrolysate has activity against both gram-negative ( $E$. coli) and grampositive ( $S$. aureus) bacteria. Three peptides having the sequences of EESETVGQR, GQSTGTGQQER, and LDALEPDNR identified in the $\mathrm{pH} 4$ hydrolysate fraction could be responsible for the activity. The antibacterial activity of these peptides, which is due to their ionic properties and secondary structure, supports the disruption of the bacterial cell membrane.

\section{ACKNOWLEDGEMENTS}

This research was supported by the Directorate Research Universitas Gadjah Mada and the Ministry of Research and Technology Republic of Indonesia through the Basic Research Grant 2020 contract no. 2963/UN1.DITLIT/DITLIT/PT/2020.

\section{REFERENCES}

Aminov RI., 2016. History of antimicrobial drug discovery - Major classes and health impact. Biochem. Pharmacol.133:4-19.

Balaban N., Collins LV., Cullor JS., Hume EB., Medina-Acosta E., Vieira da Motta O., O'Callaghan R., Rossitto PV., Shirtliff ME., Serafim da Silveira L., Tarkowski A., Torres JV., 2000. Prevention of diseases caused by Staphylococcus aureus using the peptide. Peptides 21 (9): 1301-1311.

Balouiri M., Sadiki M., Ibnsouda SK., 2016. Methods for in vitro evaluating antimicrobial activity: A review. J. Pharm. Anal. 6 :71-79.

Beaulieu L., Bondu S., Doiron K., Rioux L-E., Turgeon SL., 2015. Characterization of antibacterial activity from protein hydrolysates of the macroalga Saccharina longicruris and identification of peptidas implied in bioactivity. J. Funct. Foods 17: 685-697.

Berrocal-Lobo M., Molina A., Rodríguez-Palenzuela P., García-Olmedo F., Rivas, L. 2009. Leishmania donovani: Thionins, plant antimicrobial peptides with leishmanicidal activity. Exp. Parasitol. 122(3): 247-249.

Bougherra F., Dilmi-Bouras A., Balti R., Przybylski R., Elhameur H., Chevalier M., Flahaut C., Dhulster P., Adoui F., Naima N, 2017. Antibacterial activity of new peptide from bovine casein hydrolyzed by a serine metalloprotease of Lactococcus lactis subsp lactis BR16. J. Funct. Foods 32: 112-122.

Caron F., 2012. Antimicrobial susceptibility testing: a four facets tool for the clinician. J. Des. AntiInfect. 14: 186-174.

CLSI, 2012. Performance Standards for Antimicrobial Disk Susceptibility Tests, Approved Standard, $7^{\text {th }}$ ed.; Clinical and Laboratory Standards Institute: Wayne, Pennsylvania 32 (1): 1-53

Coon JJ., Syka JEP., Shabanowitz J., Hunt DF., 2005. Tandem Mass Spectrometry for Peptide and Protein Sequence Analysis. Biotechniques 38(4): 519- 523.

Cottrell JS., 2011. Protein identification using MS/MS data. J. Proteom. 74(10): 1842-1851.

Cutignano A., Nuzzo G., Ianora A., Luongo E., Romano G., Gallo C., Sansone C., Aprea S., Mancini F., D'Oro U., Fontana A., 2015. Development and application of a novel SPEmethod for bioassay-guided fractionation of marine extracts. Mar. Drugs 13(9): 57365749. 
Das K., Tiwari RKS., Shrivastava DK., 2010. Techniques for evaluation of medicinal plant products as antimicrobial agents: current methods and future trends. J. Med. Plants Res. 4: 104-111.

Dodds DR., 2017. Review antibiotic resistance: A current epilogue. Biochem. Pharmacol. 134: 139-146.

Fajr A., 2019, Hydrolysis of protein from castor bean (Ricinus communis l.) by USP grade trypsin and antibacterial activity assay of the resulted peptides, Undergraduate Thesis, Universitas Gadjah Mada, Indonesia

Fauland A., Trötzmüller M., Eberl A., Afiuni-Zadeh S., Köfeler H., Guo X., Lankmayr E., 2013. An improved SPE method for fractionation and identification of phospholipids. J. Sep. Sci. 36(4):744-51.

Habermann E., 1972. Bee and wasp venoms. Science 177: 314-322.

Hancock RE., Sahl HG., 2006. Antimicrobial and host-defense peptides as new anti-infective therapeutic strategies. Nat. Biotechnol. 24: 1551-1557.

Hunt DF., Shabanowitz J., Bai DL., 2015. Peptide sequence analysis by electron transfer dissociation mass spectrometry: A webbased tutorial. J. Am. Soc. Mass Spectr. 26(7): 1256-1258.

Kobbi S., Balti R., Bougatef A., Le Flem G., Firdaous L., Bigan M., Chataigné G., Chaabouni S., Dhulster P., Nedjar N., 2015. Antibacterial activity of novel peptides isolated from protein hydrolysates of RuBisCO purified from green juice alfalfa. J. Funct. Foods 18: 703-713.

Lacerda RS., Makishi GLA., Chambib HNM., Bittante AMQB., Gomide CA., Costa PA., Sobral PJA., 2014. Castor bean (Ricinus communis) cake protein extraction by alkaline solubilization: Definition of process parameters. Chem. Eng. Trans. 37: 775-780.

Mostovenko E., Hassan C., Rattke J., Deelder AM., van Veelen PA., Palmblad M., 2013. Comparison of peptide and protein fractionation methods in proteomics. EUPA Open Proteom. 1: 30-37.

Nesvizhskii AI., 2007. Protein Identification by Tandem Mass Spectrometry and Sequence Database Searching. In: Mass Spectrometry Data Analysis in Proteomics. Methods in Molecular Biology, edited by Matthiesen R., Humana Press, New Jersey, Vol. 367, pp. 87119.
Padhi A., Sengupta M., Sengupta S., Roehm KH., 2014. Sonawane, A. Antimicrobial peptides and proteins in mycobacterial therapy: Current status and future prospects. Tuberculosis 94: 363-373.

Parisi K., Shafee TMA., Quimbar P., van der Weerden NL., Anderson MA., 2019. The evolution, function, and mechanisms of action for plant defensins. Semin. Cell Dev. Biol. 88: 107-118.

Pizzo E., Zanfardino A., Di Giuseppe AMA.. Bosso A., Landi N., Ragucci S., Varcamonti M., Notomista E., Di Maro A., 2015. A new active antimicrobial peptide from PD-L4, a type 1 ribosome-inactivating protein of Phytolacca dioica L.: A new function of RIPs for plant defense? FEBS Lett. 589(19): 2812-2818.

Scheerlinck E., Dhaenens M., van Soom A., Peelman L., de Sutter P., van Steendam K., Deforce D., 2015. Minimizing technical variation during sample preparation prior to label-free quantitative mass spectrometry. Anal. Biochem. 490: 14-19.

Sila A., Nedjar-Arroume N., Hedhili K., Chataigné G., Balti R., Nasri M., Dhulster P., Bougatef A., 2014a. Antibacterial peptides from barbell muscle protein hydrolysates: Activity against some pathogenic bacteria. LWT Food Sci. \& Technol. 55(1): 183-188.

Sila A., Hedhili K., Przybylski R., Ellouz-Chaabouni S., Dhulster P., Bougatef A., Nedjar-Arroume N., 2014b. Antibacterial activity of new peptides from barbell protein hydrolysates and mode of action via a membrane damage mechanism against Listeria monocytogenes. J. Funct. Foods 11: 322-329.

Simmaco M., Kreil G., Barra D., 2009. Bombinins, antimicrobial peptides from Bombina species. Biochim. Biophys. Acta 1788 (8): 1551-1555.

Song W., Kong X., Hua Y., Chen Y., Zhang C., Chen Y., 2020. Identification of antibacterial peptides generated from enzymatic hydrolysis of cottonseed proteins. LWTFood Sci. \& Tech. 125: 109199.

Sornwatana T., Roytrakul S., Wetprasit N., Ratanapo S., 2013. Brucin, an antibacterial peptide derived from fruit protein of Fructus Bruceae Brucea javanica (L.) Merr. Lett. Appl. Microbiol. 57: 129-136.

Syka JEP., Coon JJ., Schroeder MJ., Shabanowitz J., Hunt DF., 2004. Peptide and protein sequence snalysis by electron transfer dissociation mass spectrometry. PNAS 101(26): 9528-33. 
Tran NH., Zhang X., Xin L., Shan B., Li M., 2017. De novo peptide sequencing by deep learning. PNAS 114(31): 8247-8252.

Utami WM., 2019, Identification of peptides resulting from hydrolysis of castor seed protein (Ricinus communis) with technical grade trypsin and antibacterial activity testing of the peptides, Undergraduate Thesis, Universitas Gadjah Mada, Indonesia

Wilson CR., Mengel MC., $2018 . \quad$ Ricin. Comprehensive Toxicology; $3^{\text {rd }}$ Ed. Elsevier Science BV., Amsterdam, The Netherlands pp: 202-205

Xin H., Ji S., Peng J., Han P., An X., Wang S., Cao B., 2017. Isolation and characterization of $a$ novel antibacterial peptide from a native swine intestinal tract-derived bacterium. Int. J. Antimicrob.Agents 49: 427-436.

Xue Y., Zhao, P., Quan, C., Zhao, Z.; Li, P. 2018. Review: Cyanobacteria-derived peptide antibiotics discovered since 2000. Peptides 107: 17-24.

Zhao P., Xue Y., Gao W., Li J., Li, P., 2018. Review: Actinobacteria-Derived peptide antibiotics since 2000. Peptides 103: 48-59.

Zhou J-Y., Dann GP., Shi T., Wang L., Gao X., Su D., Nicora CD., Shukla AK., Moore RJ., Liu T., Camp DG., Smith RD., Qian W-J., 2012. A Simple Sodium Dodecyl Sulfate-assisted Sample Preparation Method for LC-MSbased Proteomics Applications. Anal. Chem. 84(6): 2862-2867. 